\title{
Determinants of capital structure decisions among publicly listed Islamic banks
}

\author{
Zahid ur Rehman Khokher ${ }^{a}$ and Syed Musa bin Syed Jaafar Alhabshi ${ }^{b^{*}}$
}

${ }^{a}$ PhD Scholar, Institute of Islamic Banking and Finance, International Islamic University Malaysia ${ }^{b}$ Dean and Associate Professor, Institute of Islamic Banking and Finance, International Islamic University Malaysia

\section{CH R O N I C L E}

\section{Article history:}

Received: April 22, 2019

Received in revised format: April 282019

Accepted: May 22, 2019

Available online:

May 23, 2019

Keywords:

Capital Structure

Regulation

Bank Leverage

Islamic Bank

Emerging Markets

Capital Market

Deposit Insurance

\section{A B S T R A C T}

This research aims to examine bank specific, market and regulatory determinants of leverage and capital structure based on a panel data of publicly listed Islamic banks in 12 countries over the period 2008-2017. Apart from testing standard corporate finance parameters using both OLS and M-Estimators, this study adds several idiosyncratic and regulatory environment related determinants of leverage unique to Islamic banks. The significance of potential determinants is tested for market and book leverage as well as newly introduced 'Islamic banking leverage'. Overall, the results show that Islamic banks with higher growth opportunities, tangibility, low profitability and low risk are likely to have a high leverage. Similarly, the findings suggest important role played by debt market conditions, share of investment accounts and regulatory environment in such decisions, providing an evidence of the significance of trade-off and pecking order theory in capital structure in Islamic banks. The results are more robust for market and Islamic banking leverage, rather than book leverage. The findings offer insights to regulators, standard setters and especially Islamic banks regarding parameters to strengthen their capital, enhance resilience and thus contribute to the stability of relevant financial. This paper is among the few extant studies that focus on listed Islamic banks and tests determinants based on stock market data.

C 2019 by the authors; licensee Growing Science, Canada

\section{Introduction}

Since the establishment of first Islamic bank in 1975, currently over 200 Islamic banks are operating in the world in more than 80 countries. The size of this sector is now above USD 1,700 billion and has become "systemically important" in over a dozen countries in Asia, Middle East and Africa (International Monetary Fund, 2018). With the establishment of first Islamic bank in Suriname in South America in early 2018, this sector has established its footprints in all six habitable continents of the world. As of end 2017 , share of Islamic banking in overall Islamic financial services industry comprised $76 \%$ (Islamic Financial Services board, 2018) where main growth in assets was observed in all key Islamic finance markets - Gulf Cooperation Council countries, Southeast Asia, South Asia, Middle East and North Africa. The improved asset growth has also helped increase market share of Islamic banking in domestic markets, which has resulted in enhancing financial inclusion, deepen financial markets and mobilising fund for development in respective countries (Ahmed, 2009; Bitar, Kabir Hassan, \& Hippler, 2018). The 
increasing market share of Islamic banking is countries with large financial sectors and population, including at least three G20 countries - Saudi Arabia, Turkey and Indonesia - was considered to have financial stability implications for these markets which led the International Monetary Fund (IMF) and World Bank in May 2018 to include over a dozen countries in Asia and Middle East in their global financial sector surveillance programme.

The increasing significance of Islamic banking sector at domestic, regional and international levels has resulted in an increase of research and studies on Islamic financial sector. Islamic banks are considered to have distinct operational characteristics, risk profiles and balance sheet structures that have implications for the decision parameters of their managers. Nevertheless, only a limited literature is available on the empirical investigation of classical capital structure theories on Islamic banks and more specifically the determinants which motivate the capital structure decisions in Islamic banks. Similarly there is also a dearth of literature to suggest whether capital and leverage determinants in Islamic banks have common factors with conventional banks and firms (Bitar et al., 2018).

Investigating the determinants of Islamic bank capital is important since capital regulation is the key regulatory tool applied by the central banks and regulatory authorities on the basis of standards issued by the Basel Committee on Banking Supervision (BCBS) and Islamic Financial Stability Board (IFSB). The IFSB has already issued over 5 standards and guidance notes on capital adequacy regulation of Islamic banks.

While various capital structure theories for non-financial firms continued to evolve in the last fifty years of past century, the empirical literature on corporate finance started to converge on a few variables which can be considered to be determinants of leverage in these firms (Harris \& Raviv, 1991; Rajan \& Zingales, 1995; Titman, S. and Wessels, 1988). Most importantly, based on a large data set spanning over 50 years from 1950-2003, Frank \& Goyal (2009) studied the key factors from the previous literature proposed by various theories and tested the factors which are important to predicting firm leverage in US firms 03. The study found the evidence of six determinants as reliable factors for leverage in non-financial firms which included: market to book ratio, profitability, size, tangibility (collateral), dividend and industry average. Later, Gropp \& Heider (2010) expanded this paper and applied previously tested significant determinants for non-financial firms on the leverage of conventional banks by taking a sample of 100 largest US and 100 largest EU banks from 1991 to 2004. The study found standard determinants of capital structure of firms also apply on banks with the addition of a new variable "risk". Sorokina(2014) further expanded the above model for US banks. Apart from testing various factors previously found to be reliable determinants of firm and bank capital structure, a number of other potential factors were also included in a tested model. These new factors were found to be non-significant in another study by Frank \& Goyal(2009) in their study on non-financial firms. This study found several additional significant determinants of bank capital structure such as: growth, maturity, capital expenditures, depreciation expenses etc.

With the increasing significance of Islamic finance in global financial landscape, it is of importance to study the drivers of leverage in capital structure of Islamic bank for several reasons: First, to verify whether key determinants found significant in firm-level and bank capital literature are applicable to Islamic banks; Second, to explore whether there are additional institution-specific factors that influence capital decisions in these banks due to their unique balance sheet structure and risk characteristics; Third, to investigate to what extent legal and regulatory environment for Islamic banking in the jurisdiction impacts such decisions; and Fourth, to see whether macroeconomic variables play a significant role in Islamic banks' capital structure.

As mentioned, the studies on Islamic bank capital structure are not very common. Some papers focus on the impact of capital structure on the performance of Islamic banks (Al-Kayed, Zain, \& Duasa, 2014; Pratomo \& Ismail, 2007) whereas some others test the impact of profit sharing investment accounts 
(PSIA) on Islamic bank capital (Hamza, 2016; Hamza \& Saadaoui, 2013). Nevertheless, since 2016, several authors have attempted to specifically look into the determinants of capital in Islamic banks while testing a range of factors, which are mainly grounded in the corporate finance literature and studies on conventional banks such as (Bitar et al., 2018; Shah et al., 2017; Sheikh \& Qureshi, 2017; Thabet et al., 2017). The findings of these studies show that key determinants of capital structure found significant for firms and conventional banks such as profitability, size, tangibility, depreciation and risk are mostly significant for Islamic banks when tested for book leverage whereas macroeconomic variables such as GDP growth are not. Overall, these papers observe the evidence of trade-off and/or pecking order theory for Islamic bank capital determinants.

This paper attempts to expand the literature on Islamic banking in several ways: First, In contrast to most studies conducted on capital determinants that focus on developed markets, this paper takes sample of 34 Islamic banks from 12 jurisdictions representing emerging markets in Asia, Africa and Middle East for a 10 year period; Second, well tested corporate finance theories as well as additional parameters found significant in several studies on conventional banks have been applied and empirically tested in this paper on Islamic banks; Third, for the first time market based data is used for listed Islamic banks to calculate market-to-book ratio, dividends, risk and market leverage indicators, which were either not covered in the past studies on Islamic banks or accounting based data was used as a proxy; Fourth, along with testing book leverage and market leverage as dependent variable, a unique leverage indicator called "Islamic banking leverage" has been introduced to consider the impact of PSIA as risk absorbent; Fifth, we introduce several new potential determinants that can have potential impact on leverage in Islamic banks but are not tested in studies on capital determinates in the past; and Finally, the data has been separately tested for large, systemically important Islamic banks to examine any possible variations in the capital decisions of these banks vis-à-vis smaller and less significant banks. The results will offer insights for macroprudential policy and systemic risk control, a major focus on global regulatory reforms introduced in the form of Basel III (Dagher, Dell'Ariccia, Laeven, Ratnovski, \& Tong, 2016; Hoenig, 2013; Kellermann \& Schlag, 2013; Shin, 2011).

The remaining sections of the paper are organised as follows: Section 2 takes a look at the theoretical underpinning of capital structure theories and relevant literature on capital and leverage decisions in firms and banks. Section 3 explains the empirical model, hypotheses and expected significance and signs of various determinants. Section 4 covers empirical results whereas Section 5 offers concluding remarks.

\section{Capital Structure Theories and Exploring Significant Determinants for Banks}

\subsection{The Evolution of Capital Structure Theories of Firms and Banks}

Firms use borrowed money as an investment strategy to increase their potential return on investment. An optimal mix of equity and debt for a firm will be that results in maximisation of firm value and minimisation of the cost of capital on overall basis (Sheikh \& Qureshi, 2017). Thus, while the use of borrowed capital or debt to finance assets or making investment in various financial instruments by 'leveraging' the firm has been used since long, the theories to understand the underlying motivations started developing only in the second half of last century.

The first major attempt to theorise the capital structure in firms was made by (Modigliani \& Miller, 1958) who conjectured that in perfect markets, with no taxes and bankruptcy costs, it does not matter what capital structure a company uses to finance its operations. A further refinement of this theory in 1963 (Modigliani \& Miller, 1963) recognizes the tax benefit from interest payments and thus assumes that there are benefits to leverage within a capital structure up until the optimal capital structure is reached. (Al-Kayed et al., 2014; Miles et al., 2013). 
Since Modigliani and Miller's conjuncture of irrelevance of a firm's capital structure, the literature on capital structure has significantly evolved. Various theories have been developed over these years, offering determinants of leverage and decision making of firms on their capital structure, though the empirical analyses of these theories have sometimes offered conflicting results. Some of these theories included pecking order theory, trade-off theory, signalling theory, managerial timing theory etc (Miglo, 2010). In some other theories, the concept of "dynamic capital structure" was introduced which endeavoured to overcome the limitation of static or one-period capital structure models (Sorokina, 2014). From Islamic finance perspective, two theories are more relevant which are discussed below.

At firm level, "pecking order theory" was initially introduced by (Donaldson, 1961, 1962). This theory argues that firms have specific order preference while making decisions to finance their business (Atiyet, 2012; Myers, 1977). Due to information asymmetry between the investors and firm, the firm will choose to use internal financing in the form of retained earning instead of issuing new securities. Moreover, when the firm chooses to issue securities, it would prefer debt over equity and short-term debt over longterm debt (Myers \& Majluf, 1984).

In the next decade, (Kraus \& Litzenberger, 1973) introduced "trade-off theory" which argues that while making capital structure decisions, companies prefer to balance between tax-shield benefits and financial distress costs of debt. It helps to maximise the firm value (Atiyet, 2012). Due to the tax deductibility of interest payment on corporate debt, its use is preferred. Sometimes "agency cost theory" is lumped together into the trade-off theory which focuses on disciplining element of leverage. As firms need to pay debt to avoid liquidation, it helps to discipline the managers and minimise agency related problems (Admati et al., 2010).

As various capital structure theories for non-financial firms continued to evolve in the last fifty years of past century, the empirical literature on corporate finance started to converge on a few variables which can be considered to reliability determinate the leverage in these firms such as (Harris \& Raviv, 1991; Rajan \& Zingales, 1995; Titman, \& Wessels, 1988). As referred in the previous section, (Frank \& Goyal, 2009) study was a significant step forward in empirically analysing capital structure theories leading to a selective set of determinants. To understand the link between capital structure theories and capital determinants better, Table 1 provides a snapshot based on literature. However, capital structure of financial firms, especially banks, was considered significantly different from those of non-financial firms for two reasons: 1) banks take deposits to run their business; and 2) they are highly regulated by the governments (Gropp \& Heider, 2009).

This understanding, nonetheless, was transcended in last two decades when several researches made an attempt to study the capital structure of banks by applying well tested corporate finance theories. One of the initial models on bank capital structure was offered by (Diamond \& Rajan, 2000) who argued that banks' capital structure decisions are motivated by factors distinct from other non-financial firms due to their key role in providing funding and liquidity to the entrepreneurs' projects. Later on, several other papers tried to shed light on bank capital structure determinants which included: (Allen \& Carletti, 2013; Allen et al., 2009; Baker \& Wurgler, 2013; DeAngelo \& Stulz, 2013; Shleifer \& Vishny, 2010). However, the studies of (Gropp \& Heider, 2010) and (Sorokina, 2014) are more relevant for this paper, which found that standard determinants of capital structure of firms also apply on banks. Similarly, they found that profitable, dividend paying banks with high MTB ratio maintain considerably high level of capital, above the regulatory requirement. Overall, their findings reject the idea that banks converge to a uniform, standard level of regulatory capital when they are above the regulatory limits. Most results support various versions of trade-off and market timing theories. 
Table 1

Potential Determinants of Capital Structure in Firms and Sign Predictions

\begin{tabular}{lll}
\hline Capital Determinant & Theory & Linkage with Theory and Sign Predictions \\
\hline $\begin{array}{l}\text { Market to Book Ra- } \\
\text { tio (Growth meas- }\end{array}$ & Trade off theory & $\begin{array}{l}\text { It expects that growth reduces leverage as it increases cost of financial } \\
\text { distress and aggravates debt-related agency problems. }\end{array}$
\end{tabular}
ure)

Pecking order theory Growth possibilities and leverage are positively correlated as firms with more investments (with constant profitability) should have accumulated more debt over time.

2. Profitability Static Trade off theory A positive sign is expected as firms with higher profitability can use more debt due to: 1) smaller expected cost of financial distress; 2) tax shield on interest payments on their debt is more advantageous to them; and 3) debt-based discipline becomes an advantage.

Dynamic trade-off model A negative sign is expected due to: 1) existence of frictions in high leverage firms; and 2) these firms can passively build up profits.

Pecking order theory It expects that high profitable firms will be less leveraged (negative sign) as they prefer internal finance over external funding given that internal funds help avoid sending negative signals to the market that can impact the stock price adversely.

3. Firm (Asset) Size Trade off theory It expects large firms to be high leveraged (positive sign) as they face low risk of default due to being more diversified and hence low probability of failure. Similarly, large firms with better reputations in debt markets face lower debt-related agency costs and can raise debt easily.

Pecking order theory It suggests an inverse relationship between firm size and leverage as firms of large size are more widely known as they have a history (information aspect). It increases the preference of outside investors to invest in firm's equity rather than debt.

4. Tangibility (Collat- Agency cost theory It suggests a positive relation between tangibility and leverage for two eral) reasons: Fixed assets are easier to value for outsiders than intangible assets, expected cost of distress is reduced. Similarly, tangible assets make it difficult for shareholders to substitute high risk assets for low risk assets which results in fewer debt-related agency problems.

Close relationship of borrowers with the creditors offers an alternative to physical collateral and can help reduce agency cost and increasing leverage.

Pecking order theory Expects a negative relationship between tangibility and leverage. Low information asymmetry due to tangible assets makes equity issuance less costly.

Nevertheless, if information asymmetry is about assets in place, tangibility increases information asymmetry and result in higher leverage.

Trade off theory $\quad$ Suggests a positive relation since highly tangible firms have more chance to borrow as they can pay their debts with the help of assets being used as collateral to get more loans. Tangible assets also value higher during the bankruptcy procedures.

5. Risk Trade off theory A negative relationship is expected, since higher volatility in earnings increases bankruptcy cost and possibility of financial distress, which reduces the ability of firms to raise debt as they cannot meet future payment obligations. Similarly, unstable cash flows decrease the possibility that firm will be able to use the tax shield to full extent.

Agency cost theory Expects a positive relationship as use of debt in capital structure will lead to less commitment in risky projects or activities.

Pecking order theory Firms having more volatile stock returns are expected to suffer more adverse selection, and thus higher leverage. Moreover, such firms need to access capital market frequently to get the funding.

6. Inflation (Debt mar- Trade off theory It expects a positive relationship as real value of tax deductions on debt ket conditions) is higher when there are high expectations on inflation.

Market timing theory In debt markets, if mangers issue debt when expected inflation is high relative to current interest rates, the relationship between leverage and expected inflation is expected to be positive. 


\subsection{Studies on Capital Structure of Islamic Banks}

Empirical studies on capital and leverage decisions of Islamic banks focusing primarily on determinants have been rare until last few years. It is only since 2016, when some researchers have attempted to apply corporate finance models previously tested on conventional firms and banks on their Shari'ah compliant counterparts. In undertaking this analysis, these papers have mainly relied on financial and accountingbased data, while using book leverage or regulatory capital as dependent variable. A summary of these papers is provided in Table 2 .

\section{Table 2}

Summary of Studies on the Capital Structure of Islamic Banks

\begin{tabular}{|c|c|c|c|c|c|c|}
\hline $\begin{array}{l}\text { Author(s) and } \\
\text { Year of Publi- } \\
\text { cation }\end{array}$ & $\begin{array}{l}\text { \# of Banks \& } \\
\text { Countries }\end{array}$ & Data Source & $\begin{array}{l}\text { Data } \\
\text { range }\end{array}$ & $\begin{array}{l}\text { Determinants/ } \\
\text { Theory Tested }\end{array}$ & $\begin{array}{l}\text { Key Focus and } \\
\text { Dependent Vari- } \\
\text { able (DV) }\end{array}$ & Variables Tested \\
\hline $\begin{array}{l}\text { Thabet, } \\
\text { Shawtari, } \\
\text { Ayedh, \& Ali, } \\
2017 \text { (1) }\end{array}$ & $\begin{array}{l}263 \text { Shariah } \\
\text { compliant } \\
\text { firms in Ma- } \\
\text { laysia }\end{array}$ & $\begin{array}{l}\text { Annual } \\
\text { Reports }\end{array}$ & $\begin{array}{l}2006- \\
2011\end{array}$ & Multiple & $\begin{array}{l}\text { Testing signifi- } \\
\text { cance of deter- } \\
\text { minants on capi- } \\
\text { tal structure of } \\
\text { Shari'ah compli- } \\
\text { ant firms } \\
\text { DV: Book Lev- } \\
\text { erage }\end{array}$ & $\begin{array}{l}\text { Tax expense, de- } \\
\text { preciation expense, } \\
\text { profitability, tangi- } \\
\text { bility, Risk (Std } \\
\text { Dev of EBIT) }\end{array}$ \\
\hline $\begin{array}{l}\text { Sheikh \& } \\
\text { Qureshi, } 2017 \\
\text { (2) }\end{array}$ & $\begin{array}{l}20 \text { banks ( } 15 \\
\text { conventional } \\
\text { and } 5 \text { Is- } \\
\text { lamic), } \\
1 \text { country } \\
\text { (Pakistan) }\end{array}$ & $\begin{array}{l}\text { Annual Re- } \\
\text { ports }\end{array}$ & $\begin{array}{l}2004- \\
2014\end{array}$ & Multiple & $\begin{array}{l}\text { Testing signifi- } \\
\text { cance of } 5 \text { deter- } \\
\text { minants on capi- } \\
\text { tal structure of } \\
\text { banks } \\
\text { DV: Book Lev- } \\
\text { erage }\end{array}$ & $\begin{array}{l}\text { profitability, bank } \\
\text { size, growth, tangi- } \\
\text { bility, risk (profit } \\
\text { before taxes vola- } \\
\text { tility) }\end{array}$ \\
\hline $\begin{array}{l}\text { Shah et al., } \\
2017 \text { (3) }\end{array}$ & $\begin{array}{l}10 \text { Islamic } \\
\text { banks (in- } \\
\text { clude } 5 \text { win- } \\
\text { dows), } \quad 1 \\
\text { country (Pa- } \\
\text { kistan) }\end{array}$ & $\begin{array}{l}\text { Annual and } \\
\text { Quarterly } \\
\text { Reports }\end{array}$ & $\begin{array}{l}2006- \\
2012\end{array}$ & Multiple & $\begin{array}{l}\text { Testing signifi- } \\
\text { cance of deter- } \\
\text { minants on capi- } \\
\text { tal structure of } \\
\text { banks (using } \\
\text { book leverage) } \\
\text { DV: Book Lev- } \\
\text { erage }\end{array}$ & $\begin{array}{l}\text { Size, profitability, } \\
\text { tangibility, liquid- } \\
\text { ity, depreciation, } \\
\text { capital, growth, in- } \\
\text { terest rate, infla- } \\
\text { tion, GDP }\end{array}$ \\
\hline $\begin{array}{l}\text { Bitar et al., } \\
2018 \text { (4) }\end{array}$ & $\begin{array}{l}100 \text { Islamic } \\
\text { Banks, } 28 \\
\text { countries }\end{array}$ & $\begin{array}{l}\begin{array}{l}\text { Annual Re- } \\
\text { ports. }\end{array} \\
\text { Two market } \\
\text { indicators } \\
\text { for listed } \\
\text { banks }\end{array}$ & $\begin{array}{l}\text { 1999- } \\
2013, \\
\text { Annual }\end{array}$ & Multiple & $\begin{array}{l}\text { Impact of bank } \\
\text { and institutional } \\
\text { determinants on } \\
\text { capital ratios } \\
\text { DV: Book Lev- } \\
\text { erage, Tier } 1 \text { Ra- } \\
\text { tio }\end{array}$ & $\begin{array}{l}\text { Size, profitability, } \\
\text { liquidity, tangibil- } \\
\text { ity, risk (net loans } \\
\text { to assets), [GDP } \\
\text { growth, inflation } \\
\text { rate; oil, gas and } \\
\text { mineral rent] ; [rule } \\
\text { of law, limited gov- } \\
\text { ernment, regulatory } \\
\text { efficiency, open } \\
\text { markets, economic } \\
\text { development]. } \\
\text { For listed (market } \\
\text { to book ratio, divi- } \\
\text { dend per share, fee } \\
\text { income, net interest } \\
\text { income). }\end{array}$ \\
\hline
\end{tabular}


The findings of these studies demonstrate that key determinants of capital structure found significant for firms and conventional banks such as profitability, size, tangibility, depreciation and risk are generally significant for Islamic banks whereas macroeconomic variables such as growth in GDP are not. Overall, these papers observe the evidence of trade-off and/or pecking order theory for Islamic banks' capital determinants.

While this literature is significant in expanding our understanding on capital decisions of Islamic banks, the following observations are made: First, all but one study has focused on the data of only one jurisdiction; Second, dependent variable in all studies on Islamic banks/firms has been the book or regulatory leverage, whereas literature on the capital structure of conventional banks and firms also testes market leverage; Third, in three out of four studies, focus has been mainly given to the 5-6 potential determinants tested on conventional banks in the past, along with the addition of a few macroeconomic variables. These papers do not attempt to study several other idiosyncratic and market environment related variables that could impact the capital and leverage decisions in Islamic banks; Fourth, various definitions of "risk" variable in these studies primarily use balance sheet data, whereas theoretical literature on capital structure theory requires risk factor calculated as annual variance of stock returns. I the same token, whereas all major studies in literature have included "market to book ratio" and "dividends" among the potential capital determinants, all except one study have not tested these determinants at all; Fifth, no attempt has been made to modify the definition of leverage from Islamic banking perspective, which offer profit sharing and loss bearing Mudarabah based, quasi equity PSIA. Since PSIA holders bear the risk of losses on the investments funded by them, the leverage of Islamic banks is impacted (Hamza \& Saadaoui, 2013).

This paper aims to fill this gap by investigating all the above dimensions for a 10 -year panel data of publicly listed Islamic banks from 12 jurisdictions for over 15 potential determinants.

\section{Model Formulation and Data}

\subsection{Choice of Dependent Variable}

We start with the application of capital structure theories on Islamic banks by empirically testing the significance of various determinants using market leverage and book leverage definitions as dependent variable. Book leverage and market leverage are the most widely used definitions of leverage in literature and have their own strengths and weaknesses. In contrast to 'backward looking' book leverage, market leverage is said to be 'forward looking' measure (Barclay et al., 2006) that relies on market data that has more managerial relevance (Welch, 2004). The proponents of book leverage, however, state that it is more relevant measure since debt can be best supported by existing assets rather than opportunities for growth and that it has less fluctuation (Myers, 1977); bank regulation is based on book value (Gropp \& Heider, 2010); it has less fluctuation (Myers, 1977) and has less capital adjustment cost that market fluctuations of equity (Graham \& Harvey, 2001).

Using book leverage as dependent variable also helps to test the impact of "buffer view" on capital structure of Islamic banks i.e. whether capital structure of Islamic banks aligns with the regulatory requirements for capital adequacy or banks prefer to maintain a buffer in the form of discretionary capital beyond the stipulated requirements. The formulas for both the ratios as well as other variables tested in this study are provided in the Appendix.

In addition, a new definition of "Islamic bank leverage" has been proposed. This definition considers the contractual feature of PSIA offered by Islamic banks according to which these account holders are expected to share the losses incurred on the assets funded by them. If this expectation is true, these accounts offer an effective mechanism in reducing the leverage of Islamic banks. Fully risk absorbent PSIA will also give more room to Islamic bank managers for growth since shareholders' equity will be used to fully support the risk of assets funded by non-PSIA accounts such as current accounts. 


\subsection{Potential Determinants Tested in Past Literature}

In the basic model, key determinants found significant on firms as well as conventional and Islamic banks will be used as explanatory variable that include: market to book ratio (MTB), profitability, size, collateral (as a proxy to tangibility) and dummy for dividend payments. In line with (Frank \& Goyal, 2009; Sorokina, 2014), all factors have been lagged one year. In the second formulation, the model is tested with the inclusion of "risk" variable. Table 1 above explains the potential relationship between these variables and various capital structure theories.

The use of market-based factors such as MTB and dividend are expected to offer important insights since listing in stock market offers a disciplining tool and enhances market discipline. The listing also ensures that relatively stringent rules are applied on publicly listed banks (Bitar et al., 2018).

Tangibility is important in the case of Islamic banks since these banks are expected not to keep receivables and intangible assets beyond a specified percentage if the stock has to be considered as Shari'ah compliant. A high level of intangibility would mean that trade in their shares could be considered similar to as sale of debt, which is not Shari'ah compliant (Thabet et al., 2017). Since Islamic finance is required to be linked to real assets, tangibility factor could potentially be a significant factor. Nevertheless, due to under developed legal systems and recovery laws and procedures, enforceability of debt contracts (including Sukuk) and collateral recovery becomes expensive and tedious process, marred with uncertainty. In line with ((Frank \& Goyal, 2009), this paper uses colalteral as a substitue which is measured by investments in Shari'ah compliant securities, Sukuk, cash, land and buidling as well as other tangible assets as a percentage of total assets.

If regulation is considered a departure from (Modigliani \& Miller, 1958), a regulator can stipulate higher book equity requirements on more risky banks. If this applies, not including "risk" in the model could result in artificial importance of other variables. In order to test the veracity of this statement, the models without the "risk" variable as originally tested by (Frank \& Goyal, 2009) will provide a clue on whether this variable "drives other variables out" of this model.

In the next formulation, the model adds five additional variables for testing their significance which were earlier studied by (Sorokina, 2014). These variables are added to test the significance of following dimensions:

$\begin{array}{ll}\text { Dimension Tested } & \text { Variable } \\ \text { Supply Side Factors } & \text { Maturity } \\ \text { Growth } & \text { Capital Expenditure } \\ \text { Taxes } & \text { Depreciation } \\ \text { Debt Market Condition } & \text { Inflation } \\ \text { Macroeconomic conditions } & \text { GDP Growth }\end{array}$

Maturity serves as a proxy for low risk of default for firms with longer track record, that have more room for stockpiling retained earnings. The trade-off theory suggests that if should be positively corelated with leverage whereas pecking order theory suggests a negative relationship since mature firms have more internal resources which would reduce the need for external funding through debt. For capital expenditures, the predictions similar to MTB can be made, which is another measure of growth opportunity, its negative relationship with leverage according to trade off theory and positive correlation per pecking order theory is expected.

Depreciation factor helps to test non-debt tax shield element as tax deductions against depreciation serve as substitute for the tax benefits on the use of debt (Thabet et al., 2017). In other words, it reduces taxable 
income of firms and offer tax advantage. The trade-off theory thus predicts that firms with high depreciation expenditure will have lower leverage. The potential relationship with inflation is mention in Table 1 , whereas GDP growth helps to capture variability in cross country analysis and impact of economic conditions and shocks.

\subsection{Additional Determinants from Islamic Bank Perspective}

After studying the impact of potential determinants tested for conventional and Islamic banks in the available literature, we introduce several additional idiosyncratic and market-level determinants of leverage that apply on Islamic banks. The idiosyncratic determinants are driven by unique characteristics of Islamic banks' operations at the individual level whereas other determinants are mainly dummy variables which focus on the legal and regulatory features of a jurisdiction in which Islamic bank operates.

Two additional variables, which are based on individual bank level information, are introduced in the model: Share of PSIA in total liabilities is found to have significant and positive impact on bank leverage (Hamza \& Saadaoui, 2013). Off balance sheet is a widely ignored factor in literature while studying the leverage. However, several studies conducted by official bodies such as BCBS and Bank of Japan (BCBS, 2010; Kalemli-ozcan, Sorensen, \& Yesiltas, 2012; Kamada \& Nasu, 2010) after the global financial crisis noted that "excessive built up of on- and off-balance sheet leverage" by banks and inability of capital adequacy regulations to capture these risks was among the major causes of crisis. It was one of the reasons, Basel III reforms package introduced a non-risk weighted leverage ratio, that captures the impact of off-balance sheet items. Given the importance of this variable, it is included in the model.

After looking at the impact of bank level variables, four dummy variables that are related to regulatory and market environment at the jurisdiction level are introduced in the model that are given a value of one if exists or zero otherwise. These determinants are:

i) Availability of explicit Shari'ah compliant deposit guarantee scheme: Availability of deposit guarantee scheme by the governments could induce moral hazard and high leverage in the banking sector. (Admati, 2014; Gropp \& Heider, 2009). While only a few jurisdictions have so far offered Shari'ah compliant deposit insurance schemes for Islamic banks such as Malaysia, Sudan, Nigeria, Bahrain etc., some jurisdictions cover deposits and PSIA offered by the Islamic banks using the conventional models e.g. Turkey (Najeeb \& Mustafa, 2016). There is a need to study whether the availability of Shari'ah compliant deposit guarantee scheme has any impact on the level of leverage and capital structure decisions of Islamic banks.;

ii) The risk absorbency of PSIA [Variable Alpha has value of 1 if respective regulatory and supervisory authority has applied IFSB alpha factor more than zero] Some regulators of Islamic banks apply alpha factor proposed by the IFSB that defines the extent of risk sharing by the PSIA holders (as providers of capital or Rabbul Maal) and Islamic bank (as entrepreneur or Mudārib) (IFSB, 2013). Therefore, an imposition of IFSB alpha factor is expected to influence the leverage levels in Islamic banks;

iii) Regulatory environment for commodity Murabahah based deposits [Variable CommMur has value of 1 if regulatory and supervisory authority has allowed Islamic banks to offer commodity Murabahah based deposits to retail customers] Commodity Murabahah or Tawwaruq based deposits closely resemble the features of conventional deposit product and therefore provide an opportunity to Islamic banks to leverage their balance sheet (Hamzah, Ruzaiman, \& Gazali, 2014; IFSB, 2010). It is expected that Islamic banks operating in jurisdictions where commodity Murabahah deposits are permissible will have more leverage than Islamic banks operating in other jurisdictions; and

iv) Supervisory permission to issue debt-based Tier 2 Sukūk [Variable DebtCapital has value of 1 if regulatory and supervisory authority permits the Islamic banks to offer debt based 
Sukuk issued on the basis of Murabahah or Ijarah]. In some countries, such as in Malaysia, Islamic banks have been permitted by their supervisors to use debt- or leasing-based Sukūk (such as Murabahah or Ijarah) as a part of their Tier 2 capital (Sairally, Muhammad, \& Mustafa, 2015). The permissibility of this feature can also support higher leverage in Islamic banks.

As a final step, we separately study the behaviour of determinants of Islamic bank leverage on the information asymmetry observed in systemically important banks (SIB) versus relatively smaller Islamic banks. The designation of a bank as SIB means that it is has been considered as too-big-to-fail, which could be based on several factors such as size, cross-jurisdictional activities, complexity and lack of substitute and interconnection (BCBS, 2010; IFSB, 2013). Therefore, the managers of large banks have a perception they will always be rescued by the government, mainly from the tax payers' money, or by market forces, and therefore, they can increase their leverage un-proportionately (Shin, 2011, Nigeria, 2014).

With the growth of Islamic finance and especially Islamic banking across regions, several Islamic banks have achieved a size, cross-sector activity and market connectivity which can result in their designation as domestic SIBs by their regulators (IFSB, 2013). However, for the purpose of this study, a simpler criterion is used. According to this criterion, if an Islamic bank has asset size more than USD 3 billion and its assets are more than $1.5 \%$ of the GDP of respective home jurisdiction, it will be considered as DSIB. ${ }^{1}$ Based on this criterion, full model specifications will be separately tested for SIBs as well as relatively smaller, less significant banks.

\subsection{Data}

The explanation in Section 2.1 delineates how conceptual framework of capital structure theories of firms and banks as well as their empirical analysis relies on market-based data from publicly listed institutions. Many significant determinants such as MTB ratio, dividends and risk are based on market indicators. To fill this void, this study attempts to collect data of 34 listed and publicly traded Islamic banks from 12 countries, which include: Bahrain, Egypt, Jordan, Kuwait, Qatar, Saudi Arabia and UAE in the Middle East and North Africa region; Bangladesh and Pakistan from South Asia; Indonesia and Malaysia from Southeast Asia and Turkey from Europe. An early data set of 10 years is collected, covering a period of 2008 to 2017.

The utilisation of data for publicly listed banks that includes a wide range of market-based, accounting and regulatory indicators is a key feature or this study. Since most Islamic banks are not listed, it was quite challenging to collect the needed data for this long time period. Even in established Islamic finance markets such as Malaysia, out of total 16 Islamic banks, only one bank - BIMB Holdings Berhad - is listed. The situation is not very different in other important markets such as Indonesia, Jordan and Turkey where only one Islamic bank is publicly listed or has data of more than 10 years available on a consistent basis. It is no surprise that owing to these difficulties, most studies on Islamic banks' capital structure have used only balance sheet indicators, instead of using market related and corporate finance variables. Accordingly, the selection of banks has been made primarily on the basis of consistent availability of required indicators for the 10 -year period.

This study focuses on Islamic commercial banks that are either full-fledged banks or independent subsidiaries of conventional banks. Thus, Islamic investment banks and Islamic windows of conventional banks are excluded due to the nature of data required for analysis purposes. Further, some major fully Islamic banking markets such as Iran and Sudan are excluded from the study as the required variables from these countries were not available for any Islamic bank for the target period.

\footnotetext{
${ }^{1}$ For example, see the D-SIB selection criteria used by the Reserve Bank of India which uses asset size of banks as a percentage of GDP as one of the criteria. https://rbi.org.in/scripts/bs viewcontent.aspx? $\mathrm{Id}=2766$
} 


\section{Empirical Analysis}

This thesis uses trans-national panel data from the selected countries. The highest number of banks are from Bahrain and UAE (5 each), followed by Bangladesh, Kuwait and Saudi Arabia (4 each).

Table 3

Basic description of the sample (based on country of origin)

\begin{tabular}{|c|c|c|}
\hline Country & (Listed) Islamic Banks & \%age of Sample \\
\hline Bahrain & 5 & $15 \%$ \\
\hline Bangladesh & 4 & $12 \%$ \\
\hline Egypt & 2 & $6 \%$ \\
\hline Indonesia & 1 & $3 \%$ \\
\hline Jordan & 1 & $3 \%$ \\
\hline Kuwait & 4 & $12 \%$ \\
\hline Malaysia & 1 & $3 \%$ \\
\hline Pakistan & 2 & $6 \%$ \\
\hline Palestine & 1 & $3 \%$ \\
\hline Qatar & 3 & $9 \%$ \\
\hline Saudi & 4 & $12 \%$ \\
\hline Turkey & 1 & $3 \%$ \\
\hline UAE & 5 & $15 \%$ \\
\hline Total (12 Countries) & 34 & $100 \%$ \\
\hline
\end{tabular}

The following table shows the descriptive statistics of the sample used. For brevity, only the number of observations, mean, standard deviation as well as minimum and maximum are reported. Additionally, this study has manually checked for extreme outliers in the sample and conducted some statistical test that are robust to outliers (more discussion will be followed later).

\section{Table 4}

Descriptive statistics (2008-2017)

\begin{tabular}{lrrrrr}
\hline Variable & Obs. & Mean & Std. Dev. & Min & Max \\
\hline Lm & 336 & 0.4140 & 0.2722 & 0.0000 & 1.0000 \\
Lb & 347 & 0.8675 & 0.1018 & 0.0107 & 0.9682 \\
Li & 346 & 0.8040 & 0.1999 & 0.0107 & 0.9682 \\
Mtb & 347 & 0.3233 & 0.2832 & 0.0000 & 1.8825 \\
Profit & 347 & 0.0155 & 0.0164 & -0.1105 & 0.1274 \\
LnSize & 348 & 9.0142 & 1.9932 & 3.9299 & 17.3831 \\
Collateral & 347 & 0.3955 & 0.6129 & 0.0001 & 7.1286 \\
Dividend & 350 & 0.5086 & 0.5006 & 0.0000 & 1.0000 \\
Risk & 336 & 0.1826 & 0.1365 & 0.0000 & 0.8596 \\
Maturity & 346 & 16.1867 & 74.9009 & -51.8830 & 623.9299 \\
CapitalExp & 347 & 0.0033 & 0.0059 & 0.0000 & 0.0578 \\
Depreciation & 347 & 0.0359 & 0.2206 & 0.0000 & 1.9428 \\
Inflation & 339 & 4.5307 & 4.4662 & -4.8600 & 29.5000 \\
GDPGrowth & 348 & 5.9464 & 13.3087 & -29.5540 & 44.6080 \\
SharePSIA & 336 & 0.2172 & 0.7766 & 0.0000 & 11.6953 \\
OffBS & 311 & 2112.3110 & 3093.2230 & 0.0000 & 19455.3800 \\
DepositInsurence & 350 & 0.1714 & 0.3774 & 0.0000 & 1.0000 \\
Alpha & 350 & 0.4400 & 0.4971 & 0.0000 & 1.0000 \\
CommMur & 340 & 0.2353 & 0.4248 & 0.0000 & 1.0000 \\
DebtCapital & 350 & 0.1714 & 0.3774 & 0.0000 & 1.0000 \\
DSIB & 350 & 0.6229 & 0.4854 & 0.0000 & 1.0000 \\
\hline
\end{tabular}

Source: Author

Detailed descriptive statistics shows that mean market leverage for sample banks has shown significant increase during the 10 years period, though book leverage and, by extension, Islamic banking leverage have remained relatively consistent in this period. Market to book ratio, which reduced in the years after the financial crisis, have increased again in recent years, though fluctuation (Standard deviation) has 
relatively reduced and stabilized in the sample period. Since investors use MTB to show market's perception about the value of a stock and that how much equity investors are paying for net asset value of the firm, the high maximum values in 2008-2009 period for some Islamic banks' stocks shows their overvalued nature with high growth prospects. However, the maximum MTB values of all stocks was close to or below 1 (undervalued) in 2012-2016 period, showing challenging market environment being faced by most Islamic banks during this period.

Mean sizes of sample Islamic banks are showing increasing trend over time, though the larger size is not being reflected in profits of these institutions. A clear trend visible from dividends is that more banks are sharing profits with their shareholders in recent years, in contrast to the years immediately after the global financial crisis. Similarly, share of PSIA in total liabilities is clearly on a declining trend in the last decade in sample banks. While multicollinearity is one of the main issues in panel data analysis, this study performed Variance Inflation Factors (VIF) and pairwise correlation to check the presence of multicollinearity. According to (O'Brien, 2007), the VIF value should not exceed 10, however, in this case the maximum VIF was 2.29 for Deposit Insurance and the mean VIF was only 1.53. Similarly, the pairwise correlation reported in Table below also shows that there is no presence of multicollinearity as the value of pairwise correlation does not exceed 0.80 (Kennedy, 2008). Hence, this study has sufficient confidence that there is no multicollinearity issue in the regression analysis.

Table 5

Variance Inflation Factors of selected variables (VIF) (2008-2017)

\begin{tabular}{lrrrr}
\hline Variable & VIF & SQRT VIF & Tolerance & R-Squared \\
\hline Mtb & 1.1800 & 1.0900 & 0.8452 & 0.1548 \\
Profit & 1.4000 & 1.1900 & 0.7118 & 0.2882 \\
Lnsize & 2.0400 & 1.4300 & 0.4902 & 0.5098 \\
Collateral & 1.2200 & 1.1100 & 0.8180 & 0.1820 \\
Dividend & 1.3500 & 1.1600 & 0.7391 & 0.2609 \\
Risk & 1.2100 & 1.1000 & 0.8244 & 0.1756 \\
Maturity & 1.2500 & 1.1200 & 0.8015 & 0.1985 \\
CapitalExp & 1.1500 & 1.0700 & 0.8697 & 0.1303 \\
Depreciation & 2.1300 & 1.4600 & 0.4689 & 0.5311 \\
Inflation & 1.3400 & 1.1600 & 0.7439 & 0.2561 \\
GDPGrowth & 1.1200 & 1.0600 & 0.8919 & 0.1081 \\
ClosetoCapital & 1.0300 & 1.0200 & 0.9692 & 0.0308 \\
SharePSIA & 1.2100 & 1.1000 & 0.8248 & 0.1752 \\
OffBS & 1.6800 & 1.3000 & 0.5939 & 0.4061 \\
DepositInsurence & 2.2900 & 1.5100 & 0.4373 & 0.5627 \\
Alpha & 2.0300 & 1.4300 & 0.4915 & 0.5085 \\
CommMur & 1.7500 & 1.3200 & 0.5705 & 0.4295 \\
DebtCapital & 2.1100 & 1.4500 & 0.4746 & 0.5254 \\
\hline Mean & 1.5300 & & & \\
\hline
\end{tabular}

Pairwise correlation between selected independent variables (2008-2017)

\begin{tabular}{|c|c|c|c|c|c|c|c|c|c|}
\hline & Mtb & Profit & Ln(Size) & Collateral & Dividend & Risk & Maturity & CapitalExp & \\
\hline Mtb & 1 & & & & & & & & \\
\hline Profit & -0.0749 & 1 & & & & & & & \\
\hline Lnsize & -0.1790 & -0.0321 & 1 & & & & & & \\
\hline Collateral & -0.0659 & 0.0548 & -0.04 & 1 & & & & & \\
\hline Dividend & -0.1178 & 0.0740 & 0.1896 & 0.0923 & 1 & & & & \\
\hline Risk & -0.1134 & 0.1721 & -0.1173 & 0.0526 & -0.075 & 1 & & & \\
\hline Maturity & -0.1847 & 0.2013 & 0.0984 & 0.0212 & -0.1371 & 0.0494 & 1 & & \\
\hline CapitalExp & 0.1179 & 0.0050 & -0.1128 & 0.0032 & -0.0906 & 0.1548 & -0.0966 & 1 & \\
\hline Depreciation & -0.1830 & 0.2535 & 0.0942 & -0.0184 & -0.1646 & -0.0931 & 0.7268 & -0.0901 & 1 \\
\hline Inflation & -0.1350 & 0.1086 & -0.2793 & -0.0047 & -0.1827 & 0.4159 & -0.0835 & 0.1380 & -0.1018 \\
\hline GDPGrowth & 0.0143 & 0.0962 & -0.0774 & 0.0259 & -0.1544 & 0.0583 & -0.0211 & -0.0009 & 0.0638 \\
\hline ClosetoCapital & -0.1345 & 0.0475 & -0.0934 & 0.0415 & 0.0133 & 0.1160 & 0.0104 & -0.0212 & -0.0289 \\
\hline SharePSIA & -0.1023 & -0.0875 & -0.0511 & -0.0197 & -0.1172 & 0.0727 & -0.0464 & -0.0494 & -0.0334 \\
\hline $\operatorname{Ln}(\mathrm{OffBS})$ & 0.0364 & 0.1121 & 0.4566 & -0.1323 & 0.1492 & -0.0336 & -0.0621 & 0.0795 & -0.1532 \\
\hline DepositInsurence & -0.0598 & -0.2267 & 0.2493 & 0.2845 & 0.0984 & -0.1039 & -0.0487 & -0.1376 & -0.0706 \\
\hline Alpha & 0.0183 & 0.0048 & 0.3018 & 0.0808 & 0.2496 & -0.1420 & 0.1432 & -0.1250 & 0.1808 \\
\hline CommMur & 0.0297 & -0.1153 & 0.2113 & -0.1746 & 0.1215 & 0.0068 & -0.1207 & 0.0977 & -0.0907 \\
\hline DebtCapital & 0.0266 & 0.0665 & 0.2185 & -0.1389 & 0.0529 & 0.0809 & -0.0974 & 0.1225 & -0.0741 \\
\hline
\end{tabular}


Pairwise correlation between selected independent variables (2008-2017) cont.'

\begin{tabular}{|c|c|c|c|c|c|c|c|c|c|}
\hline & Inflation & GDPGrowth & ClosetoCapital & SharePSIA & OffBS & DepositInsurence & Alpha & CommMur & DebtCapital \\
\hline \multicolumn{10}{|l|}{ Depreciation } \\
\hline Inflation & 1 & & & & & & & & \\
\hline GDPGrowth & 0.1319 & 1 & & & & & & & \\
\hline ClosetoCapital & 0.1051 & 0.0089 & 1 & & & & & & \\
\hline SharePSIA & -0.0490 & 0.0655 & 0.0484 & 1 & & & & & \\
\hline OffBS & -0.1404 & -0.1295 & -0.0813 & -0.1091 & 1 & & & & \\
\hline DepositInsurence & -0.2304 & -0.0246 & -0.0819 & 0.0562 & -0.1858 & 1 & & & \\
\hline Alpha & -0.3369 & -0.0119 & -0.1597 & -0.0931 & 0.1892 & 0.4215 & 1 & & \\
\hline CommMur & -0.1179 & -0.0748 & -0.1014 & 0.1605 & 0.1284 & -0.0749 & 0.1082 & 1 & \\
\hline DebtCapital & -0.0627 & -0.0157 & -0.0819 & 0.2287 & 0.082 & -0.0057 & -0.1894 & 0.5528 & 1 \\
\hline
\end{tabular}

This study has used two different estimators to perform the regression analysis. While the Ordinary Least Squares (OLS) remains one of the base estimators, M-Estimator is also applied to check the robustness of the results. For ease of readers, the discussion of the models, such as model fitness and other issues will be discussed first. Then the empirical results will be discussed against the hypotheses. As mentioned earlier, three definitions of leverage will be tested separately: market leverage $\left(\mathrm{L}_{\mathrm{m}}\right)$, book leverage $\left(\mathrm{L}_{b}\right)$ and Islamic banking leverage $(\mathrm{Li})$

Hypothesis 1: MTB, profit, size, collateral, dividend and risk are significant determinants of leverage in Islamic banks

$$
\begin{aligned}
& L=\beta_{0}+\beta_{1} M T B+\beta_{2} \text { Profit }+\beta_{3} \operatorname{Ln}(\text { Size })+\beta_{4} \text { Collateral }+\beta_{5} \text { Dividend }+C_{C}+C_{t}+u_{i c t} \\
& L=\beta_{0}+\beta_{1} M T B+\beta_{2} \text { Profit }+\beta_{3} \operatorname{Ln}(\text { Size })+\beta_{4} \text { Collateral }+\beta_{5} \text { Dividend }+\beta_{6} \text { Risk }+C_{C}+C_{t}+u_{i c t}
\end{aligned}
$$

At the very first outset, this study has performed regression analysis based on Hypothesis 1 highlighted above and employed two different estimators (OLS and M-Estimators). Additionally, to capture the unobserved heterogeneity across time and at the country level, time dummies and country dummies are also included in the regression respectively. Although, OLS allows time dummies and country dummies in the regression, , for the M Estimators, they were not included. ${ }^{2}$ Furthermore, to consider heteroscedasticity and serial correlation of errors, standards errors have been clustered at the level of banks (Peterson, 2009).

Overall the model fitness is good as the F-statistics is significant at 1\% levels both for the OLS and MEstimators. Looking at the determinants of market leverage in Islamic banks, the results show that MTB, dividend and size are significant at various levels under OLS.

The positive sign of MTB shows consistency with pecking order theory whereas positive sign of size and negative sign of dividend are consistent with existing studies which find the evidence of trade off theory (Sorokina etc.). In Islamic finance related studies on capital determinates, however, MTB and dividend have not been tested or found insignificant. On the other hand, size has been found significant in most studies, with mainly positive sign (Shah et al., 2017; Sheikh \& Qureshi, 2017).

The addition of "risk" factor in the model increases $\mathrm{R}^{2}$, which is significant and negative for market leverage definition, strengthens the robustness of the model and shows consistency with standard corporate finance as well as trade-off theory (Gropp \& Heider, 2010). Profit, on the other hand, is consistent with pecking order theory as highly profitable banks are expected to be less leveraged due to reliance on internal funds. Due to constraints on the use of debt from Shari'ah perspective and under-development

\footnotetext{
${ }^{2}$ M-Estimator do not allow time dummies and country dummies to be in the regression.
} 
of capital market infrastructure in the sample Islamic bank countries, it is well expected that information asymmetry is high in these jurisdictions, which leads Islamic bank managers to rely more on retained earnings. Islamic banks are also not permitted to invest their surplus funds in interest-based securities which impacts their profitability.

5. Studying book leverage for banks is important since capital regulation is applied on book rather than market value. For book leverage definition, however, only size and collateral are significant at $1 \%$, with positive signs, whereas MTB is significant under M-estimator with a negative sign. The model is also robust at $1 \%$. The addition of risk factor does not change the results much and same three variables keep their significance. It may be noted that the sign of the significant MTB factor has reversed from a positive under market leverage to a negative under book leverage. This reversal is important and reflects that Islamic banks managers do consider the impact of agency problems and higher cost of financial distress in their leverage decisions when experiencing higher growth prospects. It demonstrates that trade off theory has an influence on Islamic banks under book leverage definition. It also shows the evidence that a pure regulatory view does not apply to capital structure of Islamic banks and that banks maintain buffer over and above the regulatory capital.

Table 6

Determinants of Market and Book Leverage in Islamic Banks

\begin{tabular}{|c|c|c|c|c|c|c|c|c|}
\hline & \multicolumn{4}{|c|}{ Market Leverage $(\mathrm{Lm})$} & \multicolumn{4}{|c|}{ Book Leverage (Lb) } \\
\hline & OLS (1) & M-Estimator & OLS (2) & M-Estimator & OLS (3) & M-Estimator & OLS (4) & M-Estimator \\
\hline \multirow[t]{2}{*}{ MTB } & $0.2486^{* *}$ & $0.3229^{* * *}$ & $0.1940^{* *}$ & $0.1907^{* * *}$ & -0.0318 & $-0.0875^{* * *}$ & -0.0503 & $-0.1047^{* * *}$ \\
\hline & $(0.1214)$ & $(0.0587)$ & $(0.0875)$ & $(0.0502)$ & $(0.0450)$ & $(0.0111)$ & $(0.0498)$ & $(0.0106)$ \\
\hline \multirow[t]{2}{*}{ Profit } & -1.3219 & $-7.0070^{* * *}$ & $-1.8722^{*}$ & $-4.1998^{* * *}$ & -0.2506 & -0.3617 & 0.1684 & 0.0515 \\
\hline & (1.3203) & $(1.2531)$ & (1.0106) & $(1.0692)$ & $(0.5681)$ & $(0.2224)$ & $(0.5333)$ & $(0.2247)$ \\
\hline \multirow[t]{2}{*}{$\operatorname{Ln}($ Size $)$} & $0.0148^{*}$ & 0.0083 & $0.0123^{*}$ & 0.0056 & $0.0118^{* * *}$ & $0.0027^{*}$ & $0.0125^{* * *}$ & $0.0038^{* *}$ \\
\hline & $(0.0073)$ & $(0.0083)$ & $(0.0065)$ & $(0.0072)$ & $(0.0030)$ & $(0.0016)$ & $(0.0035)$ & $(0.0015)$ \\
\hline \multirow[t]{2}{*}{ Collateral } & 0.0010 & 0.0393 & 0.0044 & $0.0504^{* *}$ & $0.0201^{* * *}$ & $0.0104^{* *}$ & $0.0190^{* *}$ & $0.0084^{*}$ \\
\hline & $(0.0281)$ & $(0.0252)$ & $(0.0227)$ & $(0.0213)$ & $(0.0069)$ & $(0.0049)$ & $(0.0075)$ & $(0.0045)$ \\
\hline \multirow[t]{2}{*}{ Dividend } & $-0.0937^{* * *}$ & -0.0440 & $-0.0790^{* * *}$ & $-0.0805^{* * *}$ & 0.0015 & 0.0088 & -0.0052 & 0.0023 \\
\hline & $(0.0324)$ & $(0.0337)$ & $(0.0263)$ & $(0.0287)$ & $(0.0141)$ & $(0.0064)$ & $(0.0136)$ & $(0.0060)$ \\
\hline \multirow[t]{2}{*}{ Risk } & & & $-0.7815^{* * *}$ & $-1.1171^{* * *}$ & & & -0.0339 & -0.0017 \\
\hline & & & $(0.2025)$ & $(0.1022)$ & & & $(0.0433)$ & $(0.0215)$ \\
\hline \multirow{2}{*}{$\begin{array}{l}\text { Time } \\
\text { Dummy }\end{array}$} & yes & no & yes & no & yes & no & yes & no \\
\hline & & & & & & & & \\
\hline \multirow{2}{*}{$\begin{array}{l}\text { Country } \\
\text { Dummy }\end{array}$} & yes & no & yes & no & yes & no & yes & no \\
\hline & & & & & & & & \\
\hline \multirow[t]{2}{*}{ Constant } & $0.3000^{* *}$ & $0.3593^{* * *}$ & $0.5909^{* * *}$ & $0.6096^{* * *}$ & $0.7153^{* * *}$ & $0.8855^{* * *}$ & $0.7229^{* * *}$ & $0.8821^{* * *}$ \\
\hline & $(0.1408)$ & $(0.0838)$ & $(0.1307)$ & $(0.0767)$ & $(0.0523)$ & $(0.0162)$ & $(0.0607)$ & $(0.0161)$ \\
\hline \# of & 303 & 303 & 302 & 302 & 312 & 312 & 302 & 302 \\
\hline \multicolumn{9}{|l|}{ Observations } \\
\hline $\mathrm{F}$ & $7381.1100^{* * *}$ & $12.9220^{* * *}$ & $829.2900^{* * * *}$ & $31.9041^{* * *}$ & $38.7500^{* * *}$ & $17.6966^{* * *}$ & 38.7500 & $21.5465^{* * *}$ \\
\hline \multicolumn{9}{|l|}{ Statistics } \\
\hline $\mathrm{R}^{2}$ & 0.5501 & 0.1787 & 0.6357 & 0.3935 & 0.3309 & 0.2243 & 0.3367 & 0.3047 \\
\hline Adj. $R^{2}$ & 0.5095 & 0.1648 & 0.6012 & 0.3812 & 0.2724 & 0.2116 & 0.2740 & 0.2906 \\
\hline
\end{tabular}

Standard errors in parentheses. Robust Standard errors are estimated under OLS. All independent variables are lagged one year under OLS and M-Estimator. ${ }^{*} p<0.10,{ }^{* *} p<0.05,{ }^{* * *} p<0.01$

Hypothesis 2: There are significant additional significant determinants of leverage in Islamic banks (Maturity, Capital Expenditure, Depreciation, Inflation and GDP Growth)

$L=\beta_{0}+\beta_{1} M T B+\beta_{2}$ Profit $+\beta_{3} \operatorname{Ln}($ Size $)+\beta_{4}$ Collateral $+\beta_{5}$ Dividend $+\beta_{6}$ Risk $+\beta_{7}$ Maturity $+\beta_{8}$ Cap italEpx $+\beta_{9}$ Depreciation $+\beta_{10}$ Inflation $+\beta_{11}$ GDPGrowth $+u$

With the addition of new variables to the model in both market and book leverage estimates, F statistics is significant at $1 \%$ level, though $\mathrm{R}^{2}$ is relatively lower. Similarly, collateral becomes significant in both OLS and M-Estimator in market leverage. 
Among the newly added variables, the macroeconomic factors, Inflation and GDP Growth are significant with positive and negative signs respectively. A significant positive indicator for Inflation is consistent with trade off theory as tax deductibility impact on leverage is higher with rising inflation. Depreciation is significant at $10 \%$ for only M-estimator, with positive sign, which is in contrast to trade-off theory prediction, though also observed by past studies such as (Sorokina, 2014). The result of a significant GDP growth factor is noteworthy, as this determinant is not found significant in most of the studies cited in this paper.

The results for book leverage definition largely remain consistent with the market leverage findings, though Capital Expenditure factor also becomes significant under M-estimator, showing a negative relationship with the leverage in Islamic banks. This result is in line with the results of another growth measure MTB, suggesting the application of trade off theory.

Table 7

The effect of additional variables on market and book leverage of Islamic banks

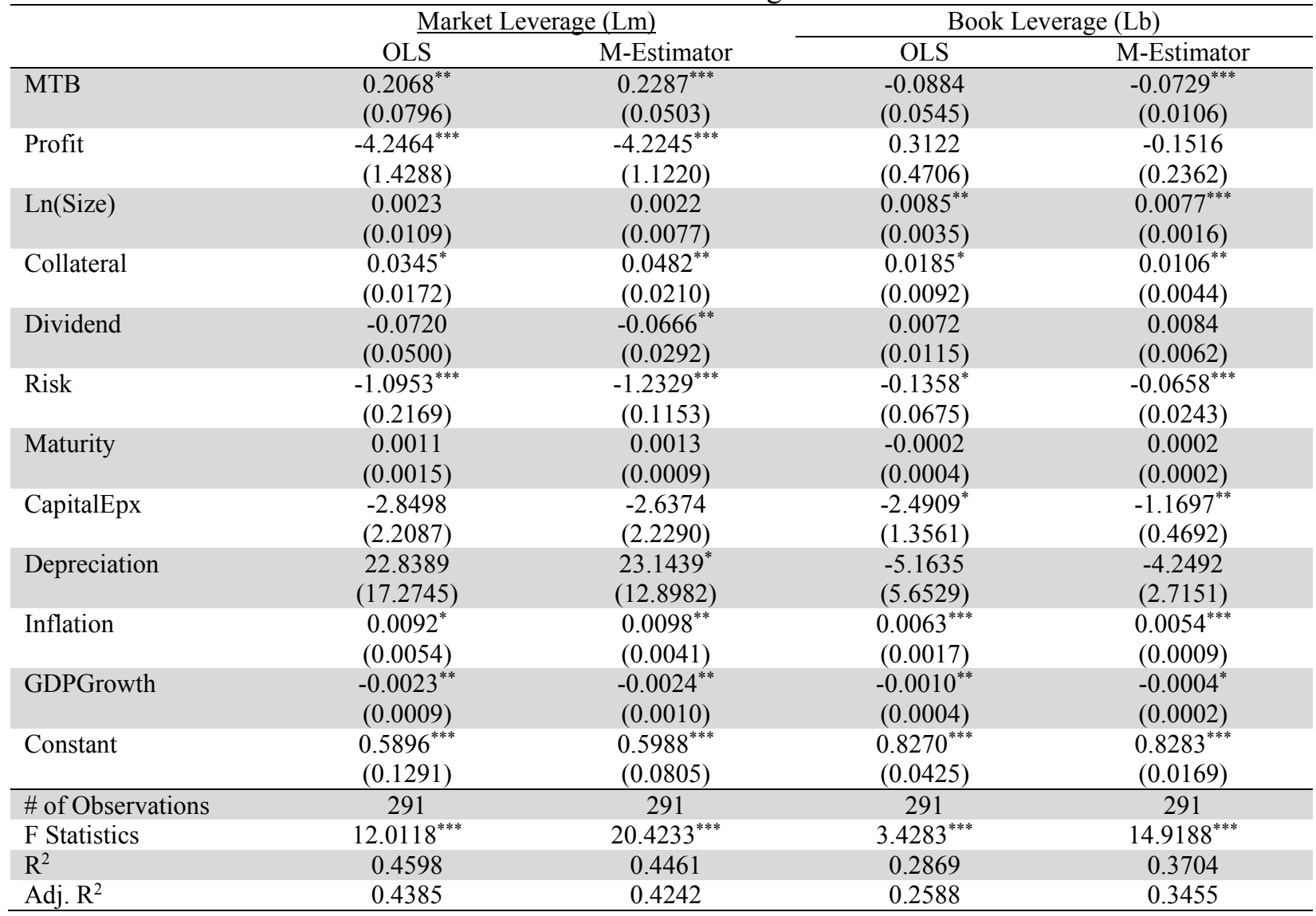

One of the unique and significant contribution of this study to the existing literature is about the proposed definition of Islamic banking leverage and its estimation. After constructing the leverage index, this indicator is used as a dependent variable to identify its determinants. As shown in the following table, overall fitness of the models is good and the explanatory power of the estimated models also high. The results exhibit that profit, size and collateral are statistically significant and have positive effect on Islamic bank leverage. Although size and collateral have a positive effect under OLS, however, the coefficient sign turns to be negative for both of the variables under M-Estimator. Interestingly, the existing studies have observed both the positive and negative effects on market leverage for size and collateral variables. Additionally, it is also observed that dividend has a positive effect on Islamic banking leverage under M Estimator. 
Further incorporating the additional determinants of Islamic banking leverage, we find the similar effect of Inflation and GDPGrowth as it was for market and book leverage. The Depreciation and MTB are found to have significantly negative effect and MTB has a positive on Islamic Bank leverage under MEstimator. In terms of model fitness, $\mathrm{F}$ statistics is significant, however, the study observed a modest $\mathrm{R}^{2}$. The risk factor is found insignificant in the base model, though become significant in other specifications with additional variables. It also holds negative sign throughout various models under OLS and M-Estimator. Similarly, macroeconomic factors Inflation and GDP Growth are found significant with consistent signs observed for market and book leverage. Based on these results, it can be confidently stated that definition of Islamic banking leverage introduced in this study offers a consistent and reliable basis for being used in Islamic banking literature.

Table 8

Determinants of Islamic Banking Leverage

\begin{tabular}{|c|c|c|c|c|}
\hline & OLS & M-Estimator & OLS & M-Estimator \\
\hline \multirow[t]{2}{*}{ MTB } & 0.0389 & $-0.0911^{* * *}$ & -0.0348 & $-0.0574^{* * *}$ \\
\hline & $(0.0616)$ & $(0.0164)$ & $(0.0727)$ & $(0.0168)$ \\
\hline \multirow[t]{2}{*}{ Profit } & $2.3519^{* *}$ & $1.5870^{* * * *}$ & $4.0047^{*}$ & $1.5371^{* * *}$ \\
\hline & $(1.1361)$ & $(0.3460)$ & $(2.0452)$ & $(0.3710)$ \\
\hline \multirow[t]{2}{*}{ Ln(Size) } & $0.0322^{* * *}$ & $-0.0072^{* * *}$ & 0.0179 & 0.0001 \\
\hline & $(0.0105)$ & $(0.0023)$ & $(0.0150)$ & $(0.0025)$ \\
\hline \multirow[t]{2}{*}{ Collateral } & $0.0874^{* * *}$ & -0.0018 & 0.0168 & 0.0033 \\
\hline & $(0.0239)$ & $(0.0069)$ & $(0.0133)$ & $(0.0069)$ \\
\hline \multirow[t]{2}{*}{ Dividend } & -0.0270 & $0.0197^{* *}$ & 0.0069 & $0.0242^{* *}$ \\
\hline & $(0.0298)$ & $(0.0093)$ & $(0.0524)$ & $(0.0097)$ \\
\hline \multirow[t]{2}{*}{ Risk } & 0.0026 & 0.0058 & $-0.2134^{* *}$ & $-0.1084^{* * *}$ \\
\hline & $(0.0637)$ & $(0.0331)$ & $(0.1047)$ & $(0.0381)$ \\
\hline \multirow[t]{2}{*}{ Maturity } & & & 0.0011 & 0.0004 \\
\hline & & & $(0.0011)$ & $(0.0003)$ \\
\hline \multirow[t]{2}{*}{ CapitalEpx } & & & -0.1893 & -0.4393 \\
\hline & & & $(2.6114)$ & $(0.7371)$ \\
\hline \multirow[t]{2}{*}{ Depreciation } & & & -15.4926 & $-12.3923^{* * *}$ \\
\hline & & & (19.2977) & (4.2678) \\
\hline \multirow[t]{2}{*}{ Inflation } & & & $0.0128^{* *}$ & $0.0070^{* * *}$ \\
\hline & & & $(0.0053)$ & $(0.0013)$ \\
\hline \multirow[t]{2}{*}{ GDPGrowth } & & & $-0.0013^{* *}$ & $-0.0007^{* *}$ \\
\hline & & & $(0.0005)$ & $(0.0003)$ \\
\hline Time Dummy & Yes & no & no & no \\
\hline Country Dummy & Yes & no & no & no \\
\hline \multirow[t]{2}{*}{ Constant } & 0.1019 & $0.9293^{* * *}$ & $0.5942^{* * *}$ & $0.8434^{* * *}$ \\
\hline & $(0.1976)$ & $(0.0248)$ & $(0.1935)$ & $(0.0266)$ \\
\hline \# of Observations & 301 & 301 & 290 & 290 \\
\hline F Statistics & $16.0200^{* * *}$ & $11.2540^{* * *}$ & $2.8462^{* *}$ & $10.3199^{* * *}$ \\
\hline $\mathrm{R}^{2}$ & 0.6597 & 0.1868 & 0.2260 & 0.2899 \\
\hline Adj. $R^{2}$ & 0.6274 & 0.1702 & 0.1953 & 0.2618 \\
\hline
\end{tabular}

Hypothesis 3: There are unique idiosyncratic variables that have significant impact on the leverage of Islamic banks

$L=\beta_{0}+\beta_{1} M T B+\beta_{2}$ Profit $+\beta_{3} \operatorname{Ln}($ Size $)+\beta_{4}$ Collateral $+\beta_{5}$ Dividend $+\beta_{6}$ Risk $+\beta_{7}$ Maturity $+\beta_{8}$ CapitalEpx $+\beta 9$ Depreciation $+\beta_{10}$ Inflation $+\beta_{11}$ GDPGrowth $+\beta_{12}$ SharePSIA $+\beta_{13} \operatorname{Ln}($ OffBS $)+u$

The study now incorporates two idiosyncratic determinants (e.g. SharePSIA and Ln(OffBS) in the model and tests for three alternatives specifications of leverage. Share of PSIA in deposits is only significant in Islamic banking specification and suggests that high share of PSIA in Islamic bank deposits results in lower leverage in Islamic banks, a result consistent with (Hamza, 2016; Hamza \& Saadaoui, 2013). More importantly, off balance sheet factor is significant for both book and Islamic leverage. The result confirms 
that the involvement of Islamic banks in off-balance sheet activity boosts their leverage. Other variables in the model broadly remain consistent with the previous tests, while retaining their signs.

Table 9

Additional unique idiosyncratic determinants of leverage in Islamic banks

\begin{tabular}{|c|c|c|c|c|c|c|}
\hline & \multicolumn{2}{|c|}{ Dependent Variable: Market Leverage } & \multicolumn{2}{|c|}{ Book Leverage (Lb) } & \multicolumn{2}{|c|}{ Islamic Bank Leverage (Li) } \\
\hline & & & & & & \\
\hline & OLS & M-Estimator & OLS & M-Estimator & OLS & M-Estimator \\
\hline \multirow[t]{2}{*}{ MTB } & $0.2259^{*}$ & $0.2583^{* * * *}$ & $-0.0808^{* *}$ & $-0.0818^{* * * *}$ & -0.0846 & $-0.0923^{* * * *}$ \\
\hline & $(0.1248)$ & $(0.0665)$ & $(0.0310)$ & $(0.0120)$ & $(0.0671)$ & $(0.0160)$ \\
\hline \multirow[t]{2}{*}{ Profit } & $-5.6057^{* * *}$ & $-6.3250^{* * * *}$ & -0.2643 & $-0.6030^{* * *}$ & 2.4179 & 0.3131 \\
\hline & $(2.0513)$ & $(1.3810)$ & $(0.4141)$ & $(0.2485)$ & $(1.8944)$ & $(0.3259)$ \\
\hline \multirow[t]{2}{*}{$\operatorname{Ln}($ Size $)$} & 0.0103 & 0.0088 & -0.0023 & -0.0028 & $-0.0296^{*}$ & $-0.0304^{* * * *}$ \\
\hline & $(0.0225)$ & $(0.0148)$ & $(0.0047)$ & $(0.0027)$ & $(0.0152)$ & $(0.0035)$ \\
\hline \multirow[t]{2}{*}{ Collateral } & $0.1085^{* * *}$ & $0.1057^{* *}$ & $0.0278^{* * *}$ & $0.0183^{* * *}$ & $0.0576^{*}$ & $0.0180^{*}$ \\
\hline & $(0.0355)$ & $(0.0408)$ & $(0.0123)$ & $(0.0073)$ & $(0.0332)$ & $(0.0096)$ \\
\hline \multirow[t]{2}{*}{ Dividend } & -0.0723 & $-0.0715^{* *}$ & 0.0023 & 0.0047 & -0.0082 & 0.0107 \\
\hline & $(0.0526)$ & $(0.0314)$ & $(0.0108)$ & $(0.0057)$ & $(0.0462)$ & $(0.0074)$ \\
\hline \multirow[t]{2}{*}{ Risk } & $-0.9941^{* * * *}$ & $-1.0512^{* * * *}$ & $-0.0738^{*}$ & $-0.0475^{*}$ & -0.0956 & -0.0276 \\
\hline & $(0.2760)$ & $(0.1425)$ & $(0.0374)$ & $(0.0257)$ & $(0.0843)$ & $(0.0336)$ \\
\hline \multirow[t]{2}{*}{ Maturity } & 0.0017 & $0.0019^{*}$ & -0.0002 & 0.0003 & 0.0011 & $0.0008^{* * * *}$ \\
\hline & $(0.0013)$ & $(0.0010)$ & $(0.0005)$ & $(0.0002)$ & $(0.0010)$ & $(0.0002)$ \\
\hline \multirow[t]{2}{*}{ CapitalEpx } & -5.5588 & -4.5483 & -1.3693 & -0.4401 & -0.2575 & -0.1269 \\
\hline & (3.6723) & (3.9568) & (1.4439) & $(0.7121)$ & $(2.8352)$ & $(0.9340)$ \\
\hline \multirow[t]{2}{*}{ Depreciation } & 1.7913 & -0.5783 & 8.1658 & $7.5942^{* * *}$ & 14.3516 & 6.0027 \\
\hline & (26.8685) & (19.8407) & (8.5579) & $(3.5707)$ & (31.2138) & (4.6877) \\
\hline \multirow[t]{2}{*}{ Inflation } & $0.0137^{* * *}$ & $0.0147^{* * * *}$ & $0.0041^{\text {**** }}$ & $0.0043^{* * * *}$ & $0.0088^{*}$ & $0.0045^{* * * *}$ \\
\hline & $(0.0065)$ & $(0.0048)$ & $(0.0012)$ & $(0.0009)$ & $(0.0052)$ & $(0.0011)$ \\
\hline \multirow[t]{2}{*}{ GDPGrowth } & $-0.0022^{* * *}$ & $-0.0026^{* *}$ & $-0.0005^{*}$ & -0.0002 & -0.0001 & -0.0001 \\
\hline & $(0.0010)$ & $(0.0012)$ & $(0.0003)$ & $(0.0002)$ & $(0.0006)$ & $(0.0003)$ \\
\hline \multirow[t]{2}{*}{ SharePSIA } & -0.0060 & -0.0116 & 0.0004 & -0.0015 & $-0.0382^{*}$ & $-0.0602^{* * * *}$ \\
\hline & $(0.0113)$ & $(0.0171)$ & $(0.0031)$ & $(0.0031)$ & $(0.0218)$ & $(0.0040)$ \\
\hline \multirow[t]{2}{*}{$\operatorname{Ln}(\mathrm{OffBS})$} & 0.0103 & 0.0086 & $0.0080^{*}$ & $0.0072^{* * *}$ & $0.0576^{* *}$ & $0.0272^{* * * *}$ \\
\hline & $(0.0190)$ & $(0.0135)$ & $(0.0044)$ & $(0.0024)$ & $(0.0238)$ & $(0.0032)$ \\
\hline \multirow[t]{2}{*}{ Constant } & $0.4164^{* *}$ & $0.4551^{* * * *}$ & $0.8656^{* * * *}$ & $0.8787^{* * * *}$ & $0.6600^{* * * *}$ & $0.9602^{* * * *}$ \\
\hline & $(0.1718)$ & $(0.1038)$ & $(0.0367)$ & $(0.0187)$ & $(0.2127)$ & $(0.0245)$ \\
\hline \# of Observations & 240 & 240 & 240 & 240 & 239 & 239 \\
\hline F Statistics & $14.4066^{* * * *}$ & $11.6625^{* * *}$ & $6.4822^{* * *}$ & $9.4399^{* * *}$ & $8.6201^{* * * *}$ & $37.1394^{* * * *}$ \\
\hline $\mathrm{R}^{2}$ & 0.4334 & 0.4015 & 0.2387 & 0.3519 & 0.3709 & 0.6821 \\
\hline Adj. $\mathrm{R}^{2}$ & 0.4008 & 0.3671 & 0.1949 & 0.3146 & 0.3346 & 0.6638 \\
\hline
\end{tabular}

Hypothesis 4: Factors related to legal and regulatory environment significantly impact the leverage of Islamic banks

$L=\beta_{0}+\beta_{1} M T B+\beta_{2}$ Profit $+\beta_{3} \operatorname{Ln}($ Size $)+\beta_{4}$ Collateral $+\beta_{5}$ Dividend $+\beta_{6}$ Risk $+\beta_{7}$ Maturity $+\beta_{8}$ CapitalEpx $+\beta$ Depreciation $+\beta_{10}$ Inflation $+\beta_{11}$ GDPGrowth $+\beta_{12}$ SharePSIA $+\beta_{13} \operatorname{Ln}($ OffBS $)+\beta_{14}$ DepositInsurance $+\beta_{15}$ Alpha $+\beta_{16}$ CommMur $+\beta_{17}$ DebtCapital $+u(5)$

To capture the effect of legal and regulatory environment, four new dummy variables are introduced in the model. The addition of these variables in the full model specification offers a unique perspective on the collective impact of corporate finance and idiosyncratic factors as well as regulation and financial safety nets on leverage in Islamic banks, which is a contribution of this study to the relevant literature.

Overall, $\mathrm{F}$ statistics and $\mathrm{R}^{2}$ results indicates that the overall estimated models are statistically robust with high explanatory power and consistent signs, especially for market and Islamic banking leverage.

For market leverage, availability of Shari'ah Compliant deposit insurance scheme is found to be significant in both OLS and M-estimation, which positively impacts the leverage in Islamic banks, a result consistent with observations of (Admati, 2014; Gropp \& Heider, 2009). While the availability of such schemes raises the moral hazard challenges, this protection helps to enhance financial stability and increased trust of fund providers on banking institutions (IFSB, 2015; Izhar \& Asutay, 2007; Najeeb \& Mustafa, 2016). This has important policy implications for deposit insurance providers which should 
design such protection with an aim to reduce information asymmetry such as applying risk-based contributions on Islamic banks. The dummy variables on the application of Alpha factor and permission to use debt-based instruments for capital are both found significant but with negative sign. It is understandable since application of Alpha factor results in PSIA treated more like equity than debt, thus having negative impact on leverage. The negative relationship of DebtCapital factor with leverage is counterintuitive as issuance of more debt-based instruments should lead to more leverage. However, it should be noted that this practice is prevalent in only three out of 12 sample jurisdictions. The results look robust as they remain same and statistically significant under both the OLS and M-Estimator. The existence of Commodity Murabahah account in Islamic banks also has significant and positive contribution on leverage, the market share of which in Islamic banking deposits is on the rise since past many years (Hamzah et al., 2014; IFSB, 2015). Some interesting result are observed when Book leverage is used as a dependent variable and regressed in full model specification. For example, under OLS, none of the legal and regulatory environment variables are found to be statically significant. However, under $\mathrm{M}$ estimator, a more robust estimate in the presence of outliers shows similar results for DebtCapital and Alpha factor as observed in market leverage specification. A relatively less $\mathrm{R}^{2}$ value is observed despite having $1 \%$ significance level of $\mathrm{F}$ statistic value.

Table 10

The full model of capital determinants in Islamic banks

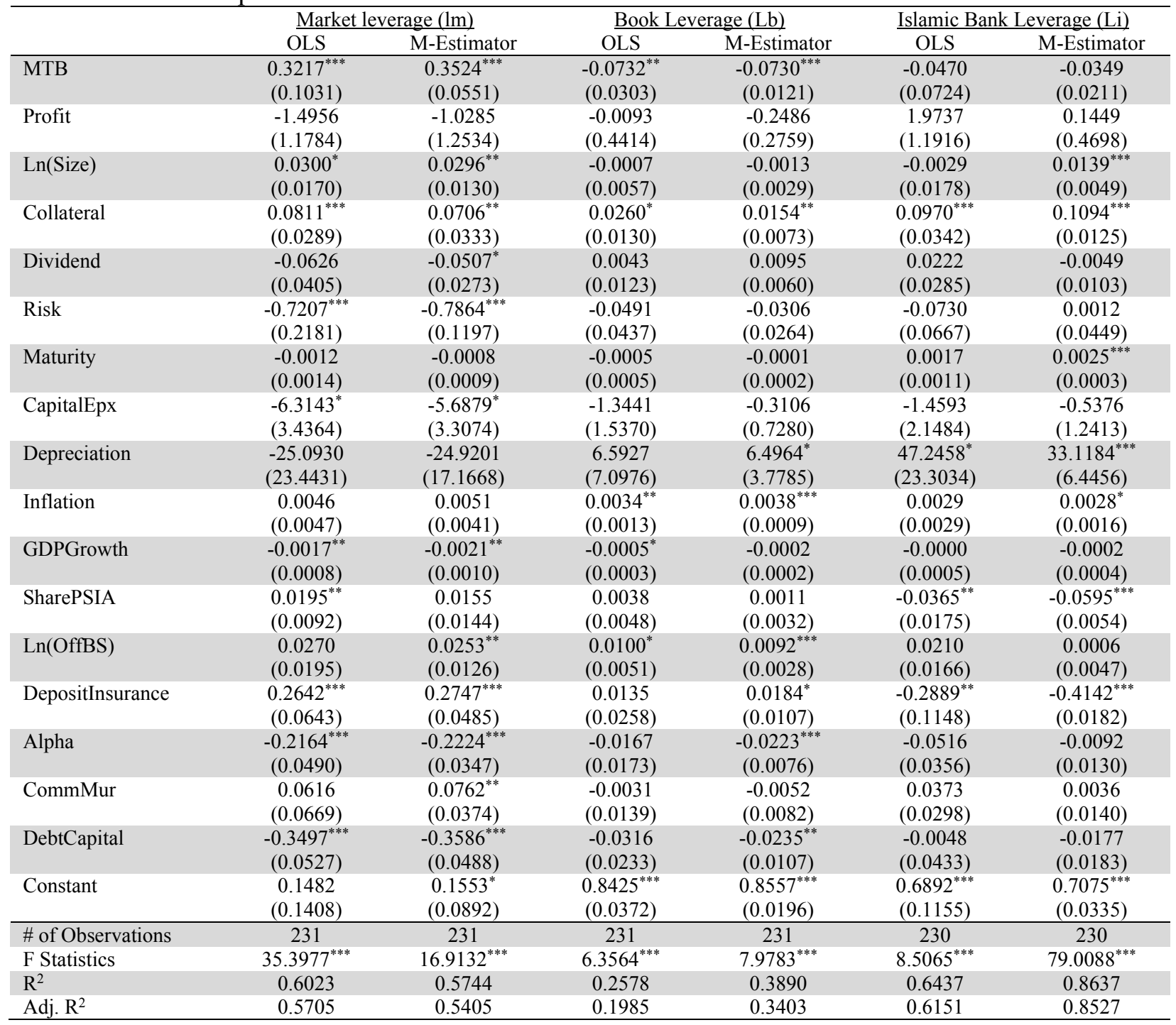




\section{Conclusion and Policy Implications}

This study uses the data of 34 publicly listed banks from 12 key Islamic finance markets, representing all the major regions where Islamic finance is being offered since over a decade to examine the determinants of capital and leverage in these banks. Over 17 potential determinants are studied in the paper, which are grounded in corporate finance, banking and Islamic finance literature.

The results lead to several noteworthy findings and extend the literature on bank capital and emerging markets: Standard corporate finance determinants that influence capital decisions in conventional firms and banks are also important factors for Islamic banks in deciding their leverage. These include indicators computed from stock market data such as MTB, dividend and risk. Moreover, looking at the application of capital structure theories using standard corporate finance variables, it is clear that most significant determinants are influenced by the trade-off theory such as size, dividend, risk, inflation and depreciation. However, some factors such as MTB and profit also show signs of pecking order theory. It shows that Islamic banks take into account the impact of agency problems and higher cost of financial distress in their leverage decisions when experiencing higher growth prospects. Similarly, the results show that profitable banks generally have low leverage as they tend to rely on internal funds in the absence of well-developed capital markets that hinders issuance of Shari'ah compliant debt instruments. The paper also finds the evidence that macroeconomic factors such as GDP growth are significant for Islamic banks. In good economic times, Islamic banks prefer to tap internal resources due to high profitability and associated retained earnings, instead of raising debt.

Findings of this paper also demonstrated that capital decisions in Islamic banks are also impacted by their funding structure and off-balance sheet items. Similarly, regulatory environment and specifically, availability of Shari'ah compliant deposit insurance has a significant impact on Islamic banks in their decision-making process for raising debt. This use of market data allowed us to test the market leverage as dependent variable in the model, along with book leverage. Similarly, this study introduced the definition of Islamic bank leverage for the first time in literature. The finding of this paper confirmed that market leverage and Islamic bank leverage specification offer more robust results for Islamic banks than the standard book leverage model. These findings have important policy implication which offer insights to banking sector and capital market regulators, Islamic finance standard setting bodies such as IFSB and Islamic banks on key factors that influence capital structure decisions in these banks. As matters related to capital market development and regulatory environment factors are beyond the remit of Islamic banks, it is imperative that development of Shari'ah compliant financial infrastructure is given priority by the regulators and policy makers e.g. introduction of new laws and regulations to strengthen primary capital market for issuance of Shari'ah complaint securities and deposit insurance scheme. These developments will help strengthen the capital base of Islamic banks, enhance their resilience and thus contribute to the stability of overall financial systems in which they operate. Since all the sample countries are part of developing and emerging markets mainly in Asia, Africa and Middle East, this study extends the literature on these markets and offers useful insights for policy makers and regulators.

The challenges in finding stock market data on a consistent basis, however, did not allow to extend this study to more countries. Thus, this paper covers a period of only a decade which can be expanded to a longer time series and more countries. The data from two countries with $100 \%$ Shariah compliant banking systems (Iran and Sudan) can offer additional insights on full-fledged versus dual banking systems. Similarly, a comparison with conventional banks data can offer a comparative framework. The impact of implementing new Basel III/IFSB capital rules can also be tested, the implementation of which started after 2015. However, it will require country level information on the implementation of these rules. The data can also be divided into large, systemically important banks and smaller banks, which can suggest decision parameters for capital and leverage in each type of banks. 


\section{References}

Admati, A. R. (2014). The Compelling Case for Stronger and More Effective Leverage Regulation in Banking. The Journal of Legal Studies, 43(S2), S35-S61. http://doi.org//10.1086/677557

Admati, A. R., DeMarzo, P. M., Hellwig, M. F., \& Pfleiderer, P. (2010). Fallacies , Irrelevant Facts , and Myths in the Discussion of Capital Regulation: Why Bank Equity is Not Expensive. The Rock Center for Corporate Governance at Stanford University Working Paper Series No. Retrieved from http://ssrn.com/abstract=1669704

Ahmed, H. (2009). Financial Crisis : Risks and Lessons for Islamic Finance. ISRA International Journal of Islamic Finance, 1(1), 7-32. Retrieved from http://kantakji.com/media/7513/c47.pdf

Al-Kayed, L., Raihan Syed Mohd Zain, S., \& Duasa, J. (2014). The relationship between capital structure and performance of Islamic banks. Journal of Islamic Accounting and Business Research, 5(2), 158181.

Allen, F., \& Carletti, E. (2013). New theories to underpin financial reform. Journal of Financial Stability, 9(2), 242-249.

Allen, F., Carletti, E., \& Marquez, R. (2009). Credit market competition and capital regulation. Review of Financial Studies, 24(4), 983-1018.

Atiyet, B. A. (2012). The Pecking Order Theory and the Static Trade Off Theory: Comparison of the Alternative Explanatory Power in French Firms. Journal of Business Studies Quaterly, 4(1), 1-14.

Baker, M., \& Wurgler, J. (2013). Do strict capital requirements raise the cost of capital? Banking regulation and the low risk anomaly. American Economic Review, 105(5), 315-320.

BCBS. (2010). Basel III. Basel III: A global regulatory framework for more resilient banks and banking systems (Vol. 2010). Retrieved from http://www.bis.org/publ/bcbs189.pdf

Bitar, M., Kabir Hassan, M., \& Hippler, W. J. (2018). The determinants of Islamic bank capital decisions. Emerging Markets Review, 35, 48-68.

Dagher, J., Dell'Ariccia, G., Laeven, L., Ratnovski, L., \& Tong, H. (2016). Benefits and Costs of Bank Capital. IMF Working Paper, (March), 1-38.

DeAngelo, H., \& Stulz, R. M. (2013). Why High Leverage is Optimal for Banks. SSRN Electronic Journal, (May). http://doi.org/10.2139/ssrn.2254998

Diamond, D., \& Rajan, R. (2000). A theory of bank capital, Journal of Finance, LV(6), 2431-2465.

Donaldson, G. (1961). Corporate Debt Capacity: A Study of Corporate Debt Policy and the Determination of Corporate Debt Capacity. Division of Research, Graduate School of Business Administration, Harvard University.

Donaldson, G. (1962). New Framework for Corporate Debt Policy. Harvard Business Review.

Frank, M. Z., \& Goyal, V. K. (2009). Capital Structure Decisions: Which Factors Are Reliably Important? Financial Management, 38(1), 1-37.

Gropp, R., \& Heider, F. (2009). THE DETERMINANTS OF BANK CAPITAL STRUCTURE (ECB Working Paper Series). ECB Working Paper Series. Frankfurt am Main.

Gropp, R., \& Heider, F. (2010). The determinants of bank capital structure. Review of Finance, 14(4), 587-622. http://doi.org/10.1093/rof/rfp030

Hamza, H. (2016). Does investment deposit return in Islamic banks reflect PLS principle? Borsa Istanbul Review, 16(1), 32-42.

Hamza, H., \& Saadaoui, Z. (2013). Investment Deposits , Risk-Taking and Capital Decisions in Islamic Banks. Studies in Economics and Finance, 30(3), 244-265.

Hamzah, A. A., Ruzaiman, F. S., \& Gazali, H. M. (2014). Islamic Investment Deposit Account Through Mudarabah \& Commodity Murabahah Contract: An Overview. In Persidangan Kebangsaan Ekonomi Malaysia ke-9 (PERKEM) (Vol. 9, pp. 28-33). Kuala Terengganu.

Harris, M., \& Raviv, A. (1991). The Theory of Capital Structure. The Journal of Finance, 46(1), 297355.

Hoenig, T. M. (2013). Basel III Capital: A Well-Intended Illusion. In International Association of Deposit Insurers Research Conference (p. 12). Basel: Federal Deposit Insurance Corporation.

IFSB. (2010). IFSB GN-2-Commodity Murabahah Transactions in Connection With Risk Management 
and Capital Adequacy Standards.

IFSB. Revised Capital Adequacy Standard (IFSB-15), IFSB 156 (2013).

IFSB. (2015). Islamic Financial Services Industry Stability Report 2015. Kaula Lumpur: Islamic Financial Services Board.

International Monetary Fund. (2018). The Core Principles for Islamic Finance Regulations and Assessment Methodology (IMF Policy Paper Series). Staff Report (Vol. 18/193).

Islamic Financial Services board. (2008). Islamic Financial Services Industry Stability Report 2018. Kuala Lumpur.

Izhar, H., \& Asutay, M. (2007). Estimating the Profitability of Islamic Banking: Evidence from Bank Muamalat Indonesia. Review of Islamic Economics, 11(2), 17-29.

Kalemli-ozcan, S., Sorensen, B., \& Yesiltas, S. (2012). Leverage across firms, banks and countries. Journal of International Economics, 88(2), 284-298.

Kamada, K., \& Nasu, K. (2010). How Can Leverage Regulations Work for the Stabilization of Financial Systems? (Bank of Japan Working Paper Series How No. 10- E-2). Bank of Japan Working Paper Series. Tokyo. Retrieved from http://www.ssrn.com/abstract $=1921201$

Kellermann, K., \& Schlag, C.-H. (2013). Occupy risk weighting: how the minimum leverage ratio dominates capital requirements: A Swiss example. Journal of Financial Regulation and Compliance, 21(4), 353-372.

Kraus, A., \& Robert H. Litzenberger. (1973). A State-Preference Model of Optimal Financial Leverage. American Finance Association, 28(4), 911-922.

Miglo, A. (2010). The Pecking Order, Trade-Off, Signaling, and Market-Timing Theories of Capital Structure: A Review. SSRN Electronic Journal, (203). http://doi.org/10.2139/ssrn.1629304

Miles, D., Yang, J., \& Marcheggiano, G. (2013). Optimal Bank Capital. The Economic Journal, 123(567), 1-37.

Modigliani, F., \& Miller, M. H. (1958). The Cost of Capital, Corporation Finance and the Theory of Investment. The American Economic Review, 48(3), 261-297.

Modigliani, F., \& Miller, M. H. (1963). Corporate Income Taxes and the Cost of Capital: A Correction. The American Economic Review, 53(3), 433-443.

Myers, S. C. (1977). Determinants of corporate borrowing. Journal of financial economics, 5(2), $147-$ 175.

Myers, S. C., \& Majluf, N. S. (1984). Corporate financing and investment decisions when firms have information that investors do not have. Journal of Financial Economics, 13(2), 187-221.

Najeeb, S. F., \& Mustafa, M. M. (2016). Strengthening the Financial Safety Net: The Role of ShariahCompliant Deposit Insurance Schemes (IFSB Working Paper Series No. WP-06/03/2). IFSB Working Paper Series. Kaula Lumpur. Retrieved from http://www.ifsb.org/docs/2016-03-31 Working Paper on SCDIS (WP-06)(Final).pdf

Nigeria, C. B. of. Framework for Regulation and Supervision of Domestic Systemically Important Banks (2014). Retrieved from https://www.cbn.gov.ng/out/2014/bsd/approved sib supervisory framework .pdf

O'Brien, R. M. (2007). A caution regarding rules of thumb for variance inflation factors. Quality and Quantity, 41(5), 673-690. http://doi.org/10.1007/s11135-006-9018-6

Pratomo, W. A., \& Ismail, A. G. (2007). ISLAMIC BANK PERFORMANCE AND CAPITAL STRUCTURE. Munich Personal RePEc Archive, (6012). Retrieved from http://mpra.ub.unimuenchen.de/6012/

Rajan, R. G., \& Zingales, L. (1995). What Do We Know About Capital Structure - Some Evidence From International Data. Journal of Finance, 50(5), 1421-1460. http://doi.org/10.2307/2329322

Sairally, B. S., Muhammad, M., \& Mustafa, M. M. (2015). STRUCTURING INNOVATIVE TIER 2 (T2) CAPITAL INSTRUMENTS UNDER BASEL III: A SHARI'AH PERSPECTIVE. ISRA International Journal of Islamic Finance, 7(2), 163-190.

Shah, M. A. R., Rashid, A., \& M. Khaleequzzaman. (2017). Capital Structure Decisions in Islamic Banking: Empirical Evidence from Pakistan. Journal of Islamic Banking and Finance, 34(June), 88103. 
Sheikh, N. A., \& Qureshi, M. A. (2017). Determinants of capital structure of Islamic and conventional commercial banks: Evidence from Pakistan. International Journal of Islamic and Middle Eastern Finance and Management, 10(1), 24-41.

Shin, H. S. (2011). Macroprudential policies beyond Basel III. In Macroprudential regulation and policy (Vol. 60, pp. 5-15). Bank for International Settlements.

Shleifer, A., \& Vishny, R. W. (2010). Unstable banking. Journal of Financial Economics, 97(3), 306318.

Sorokina, N. Y. (2014). Bank Capital and Theory of Capital Structure. Kent State University, Ohio, USA. Retrieved from https://etd.ohiolink.edu/pg_10?0::NO:10:P10_ACCESSION_NUM:kent1402795531

Thabet, O. Bin, Shawtari, F. A., Ayedh, A. M., \& Ali, F. (2017). Capital Structure of Malaysian Sharī'ahCompliant Firms. JKAU: Islamic Economics, 30(1), 105-116.

Titman, S. and Wessels, R. (1988). The determinants of capital structure choice. The Journal of Finance, $43(1), 1-19$.

\section{Appendix}

Definitions of Variables

\begin{tabular}{|c|c|c|}
\hline & Variable & Description \\
\hline 1. & Market leverage & $\begin{array}{l}\text { (market value of equity (=number of shares * end of year stock price) / market value of assets (=market value of equity }+ \\
\text { book value of liabilities) }\end{array}$ \\
\hline & & Where, Book Value of Liabilities $=$ Short Term Debt + Long Term Debt - Deferred Tax Assets \\
\hline 2. & Book leverage & 1- (book value of equity / book value of assets) \\
\hline 3. & Islamic Bank Leverage & 1- [(book value of equity + book value of PSIA) / book value of assets] \\
\hline 4. & Market to book ratio & Market value of assets (MVA)/book value of assets \\
\hline 5. & Profitability & $\begin{array}{l}\text { Operating income before depreciation /total assets, Or } \\
\text { (pre-tax profit }+ \text { interest expenses) / book value of assets }\end{array}$ \\
\hline 6. & $\operatorname{Ln}($ Size $)$ & Total Assets \\
\hline 7. & Collateral & $\begin{array}{l}\text { (total securities }+ \text { treasury bills }+ \text { other bills }+ \text { bonds }+\mathrm{CDs}+\text { cash and due from banks }+ \text { land and buildings }+ \text { other tangible } \\
\text { assets)/book value of assets }\end{array}$ \\
\hline 8. & Dividend Payment & $\begin{array}{l}\text { Dummy variable } \\
\text { (paid=1, not-paid=zero) }\end{array}$ \\
\hline 10. & Maturity & Retained Earnings / Total Equity \\
\hline 11. & Capital Expenditures & Capital expenditures/assets \\
\hline 12. & Depreciation Expense & Depreciation expense/assets \\
\hline 13. & Inflation & annual percentage change in average consumer price index \\
\hline 14. & GDP growth & Seasonally Adjusted Percentage Change from Preceding Period in Real Gross Domestic Product \\
\hline 15. & Share of PSIA in liabilities & Unrestricted PSIA /total liabilities \\
\hline 16. & Ln(Off balance sheet items) & Off balance sheet items \\
\hline 17. & $\begin{array}{l}\text { Availability of explicit deposit } \\
\text { guarantee schemes- Dummy }\end{array}$ & An explicitly announced Shari'ah compliant deposit insurance scheme \\
\hline 18. & $\begin{array}{l}\text { Risk absorbency of PSIA- } \\
\text { Dummy }\end{array}$ & Bank supervisor has applied IFSB alpha factor on Islamic banks, between zero and 1 \\
\hline 19. & $\begin{array}{l}\text { Regulatory environment for } \\
\text { commodity Murabahah depos- } \\
\text { its-Dummy }\end{array}$ & Supervisor does not object to Islamic banks offering commodity Murabahah/Tawwaruq based deposits \\
\hline 20. & $\begin{array}{l}\text { Supervisory permission to issue } \\
\text { debt-based Tier } 2 \text { Sukūk- } \\
\text { Dummy }\end{array}$ & $\begin{array}{l}\text { Supervisor does not object to Islamic banks offering Tier } 2 \text { Sukuk based on Murabahah or Ijarah or explicitly mentions this op- } \\
\text { tion in its regulations }\end{array}$ \\
\hline
\end{tabular}

